\title{
Auditors Response towards Auditing of Fair Value Measurement based Financial Reporting
}

\author{
ROEKHUDIN* \\ Accounting Department, Economics and Business Faculty, \\ Brawijaya University, Malang, Indonesia
}

\begin{abstract}
The purpose of this study is to investigate the response of auditors of large and small accounting firms for the implementation of fair value as the basis of financial statements preparation. The researcher successfully interviewed five auditors from a large accounting firm and two accountants from small accounting firm. This study has found that both auditors from large or small accounting firms argue that auditing fair value financial reports is more difficult and at higher risk when compared to auditing financial statements based on historical cost. Furthermore, in addressing these conditions, auditors from small accounting firm are not interested in auditing the fair value financial report and prefer to accept clients who do not apply fair value. On the other hand, the auditor of the large accounting firm continues to receive the auditing of fair value financial reporting. However, as compensation for increases in audit difficulty and risk, they increase audit costs. As an additional finding, especially from the aspect of legal liability, the risk of auditing assignments viewed by auditors is more daunting than audit risk. That is, the auditor is afraid of punishment as stipulated in Law No. 5 of 2011 than the failed audit.
\end{abstract}

Keywords: Fair Value, Measurement, Public Accountants, Response

Intisari: Tujuan dari penelitian ini adalah untuk menyelidiki respon auditor dari perusahaan akuntansi besar dan kecil untuk pelaksanaan nilai wajar sebagai dasar penyusunan laporan keuangan. Peneliti berhasil mewawancarai lima auditor dari sebuah kantor akuntan besar dan dua akuntan dari kantor akuntan kecil. Studi ini telah menemukan bahwa kedua auditor dari perusahaan akuntansi besar atau kecil berpendapat bahwa mengaudit laporan keuangan nilai wajar lebih sulit dan berisiko lebih tinggi bila dibandingkan dengan mengaudit laporan keuangan berdasarkan biaya historis. Selanjutnya, dalam mengatasi kondisi ini, auditor dari kantor akuntan kecil tidak tertarik untuk mengaudit laporan keuangan nilai wajar dan lebih memilih untuk menerima klien yang tidak menerapkan nilai wajar. Di sisi lain, auditor dari perusahaan akuntan besar terus menerima audit pelaporan keuangan nilai wajar. Namun, sebagai kompensasi untuk peningkatan kesulitan dan risiko audit, mereka meningkatkan biaya audit. Sebagai temuan tambahan, terutama dari aspek tanggung jawab hukum, risiko pengauditan tugas yang dilihat oleh auditor lebih menakutkan daripada risiko audit. Artinya, auditor takut akan hukuman sebagaimana diatur dalam UU Nomor 5 tahun 2011 daripada audit yang gagal.

Kata Kunci: Nilai Wajar, Pengukuran, Akuntan Publik, Respon

* Corresponding author: roe@ub.ac.id 


\section{Introduction}

The accounting measurement paradigm transforms from a historical cost based (HC) to a fair value based (FV). The advocates of fair value accounting (FVA) claim that FV measurements have an advantage over the HC based. Hitz (2007) asserts that the paradigm shift is driven by a view of the relevance of market-based measurement. Furthermore, Choy (2006), quoted from various sources, said that FV could provide better information about the company's economic conditions and provide the ability for multiple parties to understand the current market value. Therefore, Barley (2003) considers that HC-based accounting (HCA) systems are outdated and should be abandoned and replaced with a new paradigm of fair value accounting (FVA).

Francis and Schipper (1999) and Lev and Zarowin (1999) believe that the transformation of HCA into FVA is a financial statement user needs and also the efforts of the accounting standard setters' body to restore the relevance of financial information. Choy (2006) explains, the Financial Accounting Standards Board (FASB), and the International Accounting Standards Board (IASB) believes that market value capability is an efficient and unbiased estimator of future cash flows. However, Choy also asserts that the situation can be achieved if two conditions can be met: (1) there is a market price that cannot be influenced by the management of the company (although it is not perfectly competitive), and (2) the market price can be independently observed to make accurate estimators for the liquid market.

Conceptually, the transformation of the $\mathrm{HC}$ base into an FV base resulted in the conceptual framework of the preparation of financial statements prepared on the basis of $\mathrm{HC}$ to be obsolete and should be revised. Therefore, IASB and FASB work together to develop a conceptual framework for the preparation of FV-based financial statements. Furthermore, for the first time, the IASB and the FASB in July 2006 (FASB, 2006) published Discussion Paper, Preliminary Views [on an improved] Conceptual Framework for Financial Reporting: [The] Objective of Financial Reporting and Qualitative Characteristics of Decision-Useful Financial Reporting Information (ED-CFFR) (FASB, 2008). Thus, this draft is both a revision and a 
replacement for SFAC. 2: Qualitative Characteristics of Accounting Information (FASB, 1980).

Furthermore, to achieve the objectives outlined in the new basic framework, in November 2006 IASB / FASB published a discussion material on Fair Value Measurement (FVM). Based on inputs and comments from other stakeholders, in May 2009 IASB successfully issued the Exposure Draft: Fair Value Measurement (EDFVM) and then in May 2011 was officially published into IFRS 13: Fair Value Measurements. The standard content is requiring companies to measure assets, liabilities, and equity instruments using FV. Thus, it is not wrong if FV becomes the whole IFRS spirit. Ball $(2005,22)$ says:

"The fair values accounting rules in IFRSs [International Financial Reporting Standards] place considerable faith in the "conceptual framework" that IASB and FASB are jointly developing."

These changes indicate that environmental changes are slowly but surely have an impact on the fundamental accounting paradigm. The change also marks the fall of the $\mathrm{HC}$ paradigm and the emergence of a new paradigm of FV as its successor. Consequently, all HC accounting models should be replaced with new FV-based calculation models. Responding to this change, Fujioka $(2008,1)$, quoting Biondi \& Suzuki (2007), stated that:

"...the whole calculation regime is changing in our socio economy under the IAS/IFRS which pursues for the sake of international transparency, international comparability and subsequent efficiency of the world's financial markets."

In short, accounting objectives have shifted. If the $\mathrm{HC}$ accounting system is designed to facilitate accountability functions, the accounting system of FV accounting bases is designed to provide useful information in making economic decisions for interested parties (Ijiri 1975, ix). Thus, the purpose of the financial 
statements has been changed from as a means of accountability to being a means of providing information for decision making. The result is not only reliability neither critical, because it is replaced with representational faithfulness, but verifiability as a component of reliability also becomes unimportant. Thus, if in HC-based accounting the qualitative characteristics of verifiability become one of the important qualities of financial statements (SFAC No.2, FASB, 1980), in FV-based accounting these qualitative characteristics are placed as supporting qualitative characteristics of relevance and representational faithfulness. In fact, according to Mautz \& Sharaf $(1961,42)$ verifiability of financial statements and financial data is the most important postulate among others.

The concept of FVM among public accountants is not a new issue. For example, The Federation of European Accountants in 2001 issued a guideline explaining the principles that are important to the overall need to be used as a valuation company, especially in the case of small and medium-sized companies. Furthermore, in 2003 the American Institute of Certified Public Accountants (AICPA) has published Auditing Fair Value Measurements and Disclosures (AU Sec. 328) (AICPA, 2003) which refers to Statement on Auditing Standards (SAS) no. 101 and 113. AICPA (2007) also publishes Standards for Valuation Services (SSVS 1) on "Valuation of Business, Interest Ownership, Security, or Intangible Assets" enacted after January 2008. The purpose of the issuance of this standard is to improve consistency and the quality of practice among AICPA members in conducting business valuations. Furthermore, in February 2008 the International Auditing and Assurance Standards Board (IAASB) issued the International Standard on Auditing (ISA) 540 (Revised and Redrafted): Auditing Accounting Estimates, Including Fair Value Accounting Estimates, and Related Disclosures (IAASB, 2008). This standard governs the auditor's responsibilities concerning accounting estimates, including FVM, and disclosures in the audited financial statements. This standard also provides the requirements and guidance on misstatements of individual accounting estimates and indicators of the possibility of bias. 
FV measurement prioritizes input measurement techniques. Using these criteria, SFAS 157 (paragraphs 22-30) and ED-FVM (paragraph 43-54) divide FV into three levels: level one (FV-L1), level two (FV-L2), and level three (FV-L3). Quoted prices measure FV-L1, and FV-L2 is measured by input other than quoted market prices in the FV-L1 category which can be observed either directly or indirectly. While FV-L3 is measured by measurement input which cannot be observed by using market price, that is using estimation based on input and method decided by management.

It must be emphasized that the primary business of auditors is to conduct audits of financial statements. However, auditors have limited ability to audit FV assets or liabilities because the accountants are not educated as an appraiser. Also, it should be understood, as mentioned above, that they have no authority to determine the measurement of FV assets or liabilities. The company's management owns such an authority. Therefore, Benston (2008) reminded of the importance of the independence of auditors on the determination of FV by management.

To determine whether the financial statements in this report are true or false, the auditor must verify. Mautz and Sharaf assert, if the financial statements cannot be verified, there is no reason for the existence of auditing (Mautz and Sharaf, 1961, 4243). King (2006: 82) asserts "... in absence of quoted market price, most values [FV of assets or liabilities] are not auditable". Furthermore, King $(2008,3)$ said the important point is, except the FV-L1 value, all measurements involving the policy cannot be audited because the auditor has little evidence. Therefore, Pannese and DelFavero (2010: 45) said that: "... FV accounting could put reliable auditing of financial reporting at [high] risk."

The placement of verifiability as an enhancing fundamental qualitative measurement indirectly makes it part of the FV asset base and liability measurement requirements as outlined in the ED-FVM (IASB, 2009) and SFAS-157 (FASB, 2006). Why is that? In FVA, the valuation of assets or liabilities of the financial statements is no longer based on actual transaction value, except at the date of acquisition, but on market price estimates. Therefore, the verification of the truthfulness of FV assets and 
liabilities presented in the financial statements is no longer able to be verified based on actual evidence of transactions but is based on evidence of estimation results.

The condition is very contradictory to the audit postulate that verifiability is at the most important position among the others. It is because of the importance of variability in accounting figures presented in the financial statements. Mautz and Sharaf (1961: 42) say that the reports and financial data must be verifiable. If financial data cannot be verified, there is no reason to maintain auditing. Therefore, if we abandon that assumption, we do a very subjective auditing (Mautz and Sharaf (1961: 42-43). Likewise, King (2008: 304) states that except for FV level 1, all judgments involve judgment (policy). Moreover, any judgment cannot be audited.

The above criticism is acceptable because the auditor provides an opinion based on audit evidence. Mautz and Sharaf (1961), in some parts of his book entitled The Philosophy of Auditing, stated that the existence of evidence is fundamental to the auditor as a basis for determining the adequacy of the evidence to support his opinion. Therefore, to know whether the FV financial report is presented fairly, the auditor must understand how to verify. That is, the auditor should understand what is going on behind the FV figures presented in the financial statements to ensure the accuracy of his presentation. If it cannot be fulfilled, Mautz and Sharaf state (1961: 43):

“... the preposition in financial statements and report cannot be accepted as having real meaning until steps [verification] have been taken [by auditors] to indicate their verifiability (p. 43, pr. 2)”.

“...In absence of quoted market price, most values [FV of asset or liabilities] are not auditable (King, 2006: 82)... [and]... Auditor will have little evidence for testing... [therefore]...FV accounting could put reliable auditing of financial reporting at [high] risk." (Pannese and DelFavero, 2010: 45).

The public accountant task is to increase the user's trust towards financial statements. That is, it provides reasonable assurance that the financial statements are presented fairly. However, such trust may be difficult to obtain if the inputs used to 
determine the FV figures presented in the financial statements are partly, in particular, FV-L-3, involving management judgment. This method is vulnerable to management manipulation due to opportunistic attitudes, excessive optimism, or overpriced. The impact of this practices not only results in the information content of financial statements being blurred (noised) but also the financial figures presented are unclear, and their reliability is questionable. Therefore, in carrying out its role, auditors are expected to be aware of the need for preliminary understanding and rules relating to FV-based accounting, including disclosure, and considering its application (IAASB, 2008). The auditor also should understand the company and its environment, including the control environment, as a basis for identifying and assessing the risk of material misstatement of the accounting estimate.

In conclusion, the above description illustrates that the direction of change from $\mathrm{HC}$ to $\mathrm{FV}$, whatever the argument is, brings FV to an essential part of accounting standards that have great significance for broad accounting development including auditing. The problem is, based on the explanations and the statements of Mautz and Shraf (1961) and King (2008) above, except for the auditing of FV-L1, the difficulty and the risk of incorrect opinion becomes high. The critical question is how the auditor responds to the above situation?

\section{Research Method}

Based on the research problem, this research is designed as qualitative research to understand the response of auditors of small and large public accountant firms to FV as a measurement of accounting and presentation of financial statements. This method is in line with Creswell's $(1998,15)$ explanation that the qualitative method is a process to gain an understanding of social or human problems.

Research data is primary data, and its form is qualitative. This data is obtained from the results of in-depth interviews between researchers with auditors from small and large public accounting firms as informants. The selection and determination of the informants were done based on judgment and the adequacy of research data. This method is done by contacting several auditors that are well known by the researchers. 
Interviews were conducted during the first six months of 2013 and updated again in the first half of 2017.

Based on the above method, seven auditors were selected as informants consisting of two auditors from small accounting firms and five auditors from large accounting firms. Auditors from the small accounting firm are (1) SPHD (the owner and manager of Suprihadi and Partner Public Accounting Firm), (2) Warto (the owner and manager of Wartono and Partner Public Accounting Firm). Furthermore, 4 informants of the large accounting firm are: (1) MJW (the managing partner of Public Accounting Firm of PWC Indonesia), (2) EI (the managing partner of Public Accounting Firm of Deloitte \& Toutc and Tomatsu Indonesia), (3) DW (the auditor of Public Accountant Firm of Amir Abadi Jusuf), (4) EI (the vice managing partner of Public Accounting Firm of Deloitte \& Toutc and Tomatsu Indonesia) (5) Mr. X (the partner of Public Accounting Firm of PWC Indonesia).

Data analysis was done by these following steps: (1) Description of data. At this stage, identification of data from interviews with informants was made. (2) Data transcription is to translate the results of interviews into writing to facilitate the next analysis. (3) Data mapping. This is the data reduction method used by researchers to (a) identify important themes revealed in the description; (b) choosing an important theme based on communality within and between narratives based on the centrality and importance of the theme and not on the frequency of occurrence, (4) Subjective reflection is data analysis performed by discussing one data with other related data to gain an understanding of auditor's response to fair value implementation. (5) The final step is the process of abstraction or conclusion.

\section{Results and Discussion}

The transformation of the $\mathrm{HC}$ base into an FV base is recognized by auditors of small and large public accounting firm to have an impact on increasing difficulty level of FV financial statements auditing. However, there is a difference between the responses between the two. 
First, auditors from large accounting firms continue to receive audits of FV's financial statements. However, they view the difficulty of auditing as an audit fee function. This means that auditors from large public accounting firms will seek compensation in the form of increased audit fees for additional work for review of FV calculations made by management. Secondly, by contrast, auditors from small public accounting firms are not interested in auditing FV-based financial statements. This is done by avoiding accepting the assignment of FV-based financial statements. Therefore, auditors from small public accounting firms choose clients who apply the International Financial Reporting Standards for Small and Medium Enterprises (IFRS for SMEs) or Financial Accounting Standards for Entities without Public Accountability (SAK ETAP).

The above reality, about the resistance and compensation of FV audit fees, is a form of real response to a higher risk of auditing FV-based financial statements when compared to the auditing risk of HC-based financial statements. The justification of their attitude is built on four things: (1) the human resource capacity of the public accountant office and client readiness in applying FV, (2) verifiability and observability of FV measurement inputs, (3) reliability and validity of FV estimation, and (4) increasing the risk of assignment. To be more focused, the following discussion is limited to the last three aspects only.

\subsection{Verifiability and Observability: Proof of FV Truthfulness Problems}

The fields of history, law, and auditing are some of the fields among the various areas that use evidence to answer doubts and to increase trust (Mautz and Sharaf, 1961: 87). Therefore, the role of the auditor, in the field of auditing, is very important to increase the confidence that the figures presented in the financial statements are not materially misstated. A public accountant achieves such quality if sufficient audit evidence is obtained as a basis for providing opinions on the audited financial statements.

In the past, in an HC-based accounting environment, audit evidence is easily obtained by the auditor. The physical evidence of the transaction supports the 
existence of the value (rupiah) contained in the financial statements. Thus, no asset or liability value is engineered in the HC-based. All assets or liabilities are recorded accurately following the transactions and events. This is an advantage of the HC-based because the proof of the transaction can be verified. Therefore, according to Mautz and Sharaf, the measurement method of financial accounting and reporting using the basis of HC (1961) shows the truthfulness of accounting numbers that can be observed and verified based on evidence of transactions.

The situation mentioned above is very different when compared with FV based accounting. Transaction evidence is no longer a verification reference. In FV-based accounting, the measurement of asset or liability values is based on quoted market prices or estimated market prices. Therefore, the adoption of an FV basis can only be applied in perfect market conditions, where the price of financial instruments and asset or liability prices are fully available in the active market (Rayman, 2007). However, such markets are not always fully available. Consequently, under certain conditions, especially when FV is at level 3, FV measurements are based on estimates based on unobserved inputs and models that management develops subjectively.

MJW, in this regard, explains that many securities which market prices cannot be observed. He also acknowledged, when a crisis occurs, even though securities market prices are available, market price securities are not entirely reliable as a basis for FV measurement. MJW explains:

"... The unobservable FV occurs only in times of crisis. At such a time, since the market price of a securities claimed represents an unfair market price, it is necessary to develop another model of valuation."

In line with MJW, the EI states that not all market prices of assets, even financial assets, can be observed in active markets. He gave an example of the application of FV to the land concessions his client bought from the government. The client's most significant difficulty is when to calculate the FV on trees or plants (biological assets) 
that exist on the land. In fact, with the difficulties encountered in implementing the FV, EI said that his client is not willing to implement FV. EI states:

"The problem is also complicated when it comes to implementing FV in plantation companies. The case is similar to the application of FV on concession land (forest). When forest concessions are obtained from the government, on land there are trees or forest plants. The problem is determining the acquisition price of the land concession. If FV concessions are only calculated from concession fees, the value is meager. The determination of the FV of trees in the concession area is not easy. In this case, I have to discuss it for a month or two and have not finished yet."

DW, another informant, underlines MJW and EI opinion, said that:

"FV is difficult to apply especially to the plant's biological assets. Market price (FV) does not exist. To determine the FV of a biological asset, the difficulty is in determining the input value and measurement technique."

Therefore, when market prices are not available, FV measurements are dominated by measurements using inputs and assessment models developed by management. However, such a model is acceptable but unavoidably high management subjectivity. MJW did not reject it. However, he said:

"... Subjectivity is contained in the cash flow estimates and assumptions that have been developed by management, while the measurement technique is standard. Therefore, when auditing, such as cash flow, is not enough to see the existence of estimates developed by management. Auditors should look at the models, assumptions, and discount factors used by management."

The above explanation explains that the observability, and verifiability of market prices as the basis of $\mathrm{FV}$ measurement becomes the key in determining the 
truthfulness of FV. Since the market price of an asset or liability is not always available, the truthfulness of the FV measurement will be different at each FV level.

\subsection{Reliability, Validity, and Audit Risk}

When FV is in L1, audit evidence on assets or liabilities can be observed from quoted market prices such as stock prices in the stock market. Measurement of FV at this level is undoubtedly related to its validity and reliability. According to Mautz and Sharaf (1961), the truthfulness of FV at this level is high because the reliable evidence supports it as it can be verified, for example, the stock market price. However, there is no guarantee that stock prices are always stable. History shows that in times of economic and financial crisis, the market price of financial instruments tends to increase or decrease sharply. Under such conditions, although the market price of financial instruments can be observed, the stock price no longer reflects the FV of the asset. MJW asserted that:

“... In times of crisis, stock prices fluctuate very sharply. Stock prices may rise or fall suddenly. The issue is whether the stock market price can be used as a reference [in determining FV] or not? The problem is stock prices do not reflect fair market prices. Therefore, other measurement models should be developed."

Unlike the FV-L1, when FV is at level 2 the market price of the asset or liability can be observed in the market although the price varies. For example, two or more identical assets which function and acquisition price are similar but operated in a different location, it could be the market price immediately after the acquisition is different. This is the impact of measuring FV assets or liabilities that depend entirely on the subjectivity of management in choosing comparative inputs as the basis for FV determination. Such conditions were realized by IASB (2009) that: 
"... determination [of FV Machine held and used] is made on the basis of the relative subjectivity of the [measurement] inputs, considering the degree of comparability between the machine and the similar machines."

Inline of the IASB, MJW stated that:

"... It is tough to justify a particular construction or machining and its cost, including installation costs, transportation and test runs, at prices generated by others. No two sugar factories or two gas stations are similar in price, although they are similar."

The subjectivity factor of choice of FV-L2 measurement input, although it has considered the degree of comparability between two or more similar assets, has resulted in the difficulty of making it an objective justification of the subjectivity of judgment.

FV measurement subjectivity levels higher than the previous two measurement models when FV is at FV-L3. This is because market prices cannot be observed in an active market. Under such conditions, the FV measurement is entirely determined by the subjectivity of management. Penman (2007: 41) says that:

"...if fair value is based on an estimate of market price (rather than value-inuse), permits 'unobservable inputs' that reflect the reporting entity's assumptions about assumptions that market participants would use in pricing the asset or liability."

To avoid such situations, ED-FVM prohibits the use of a specific entity value and must use non-specific entity values. ED-FVM requires FV measurement using exit price and prohibit entry price. That is, an entity should not measure the FV of the assets under its control by using a specified value that is self-determined, even though logically they are the best understood the condition of the assets under their control, which the other party does not know. Therefore, ED-FVM allows the use of a cost base. However, this base requires an entity to use a replacement cost from the buyer's 
perspective (nonspecific entity value) and not from the selective entity value. As cited by Danbolt and Rees (2008: 272), Guo et al., (2005) criticized that:

"In the absence of prices derived from competitive markets incorporating the value estimates of a large number of investors who are independent of management, the estimated values are indeed often based on the work of experts. These experts have to value assets with different characteristics, including intangibility, for which precise value [validity of FV] is hard to attribute."

Therefore, the question is who is the most responsible for measuring $\mathrm{FV}$ if market prices cannot be observed? Answering this question, MJW says that: "the company together with the appraiser and the actuary are the responsible parties" This means that the role of appraisal and actuary is critical in measuring FV assets or liabilities. They are independent bodies entitled to take measurements of FV assets or liabilities. However, it should be remembered that appraisal and actuary work cannot be separated from assumptions. Similar to other professions, they do not guarantee the measurement results are 100 percent true. MJW explains that:

"Appraisal is not responsible for the baseline data, such as estimated cash flows made by management. Therefore the auditor is the last party to verify the management work. Therefore, the auditor should include an additional fee for the work of reviewing FV estimates made by management and appraisal."

MJW illustrates clearly that those auditors from large accounting firms are cautious in responding to $\mathrm{FV}$ as the basis for financial measurement and reporting even though the company has requested an appraisal for FV measurement. That is, this warning reflects the high FV auditing risk that auditors have to face. Therefore, they will exchange the risk with additional audit fees as compensation.

Instead, this study found that the attitude toward FV measurements of accountants from a small public accounting firm is very different from the accountant's attitude 
from a large public accounting firm. According to SPHD, accountants from small public accounting firms choose to avoid risk by selecting clients who apply the International Financial Reporting Standards for Small and Medium Enterprises (IFRS for SMEs) or Financial Accounting Standards for entities without public accountability (SAK ETAP). The main reasons for this choice are the limited human resource expertise of small public accounting firms and clients' readiness to implement IFRS or FV. Logically, this choice can be understood because IFRS is FV based while IFRS for SMEs or ETAP is HC based. Warto, the owner, and manager of Public Accounting Firm of Warto and Partners, also explained that the auditor's efforts in FV audit are very high. According to him, the difficulties faced by auditors are mainly related to FV auditability, namely the availability of documents. Warto states that:

".. Until now, the audit work is based on the proof of the transaction. FV assessments by third parties (independent consultants or appraisals) are easier to track because their documents and reports are available. However, if the corporate management itself makes FV judgments, it is difficult to assess the objectivity or fairness of the work if the documents or minutes of the committee are incomplete. For example, the assessment of land and buildings is easy because it has a sales price determined by the Indonesian government that we call as the sales value of tax object or NJOP. However, the objectivity of the old asset valuation results is hard to believe because the price is not available in the active market."

Referring to the above exposures, all informants agreed that company management could utilize appraisal services to estimate FV assets or liabilities that do not have an active market. Nevertheless, this practice is still possible for management, intentionally or unintentionally, to make estimations and judgments to create positions that have benefits for themselves. Every judgment creates a grey area and tends to be biased. In response to this problem Gunn (2008: 42) states: 
"...even when audit evidence supports the reasonableness of individual accounting estimates, the overall picture presented by financial statements may in face distorted. Such an outcome may arise through bias in management's judgment, the cumulative effect of which is the failure of financial statements to fairly present the entity's financial results and position".

As a result, testing estimates are not easy and risky for the auditor. Pannese and DelFavero $(2010,45)$ stated that:

"FV accounting could put reliable auditing of financial reporting at risk, since the current market for assets and liabilities may not be reflective of the true underlying worth of the asset or liability".

In line with the above opinion, JOPI states that FV auditing is more difficult when compared to the $\mathrm{HC}$ audit because FV auditing is essentially auditing the model created by management. King $(2006,82)$, cites the opinion of Douglas Carmichael (PCAOB Chief Auditor) who explained that: "... in the absence of quoted market price, most values are not auditable". Why is that? Answering this question, Pannese and DelFavero $(2010,45)$ argued that:

"Auditor will have little evidence for testing value assigned to the level three assets/liabilities where market value is based on managements' assertion, not factual acquisition prices or market quotes."

EI also recognizes the auditor's difficulty in verifying the validity of FV-L3. He says that:

"If the FV reported in the financial statements is over value, due to its inability [obtaining adequate FV audit evidence], then the auditor provides an unqualified opinion, then this may jeopardize his / her professional career. 
And, if later found guilty of giving opinion [by the court], then the accountant could be imprisoned."

In line with EI ideas, MR. X reveals that:

"If I am a signatory to the financial statements, the more I understand the FV measurements, the more I will fear. However, if all parties are wrong [auditors, appraisals, and companies], then nothing will happen. So, if all parties are equally wrong, then no one is harmed. Therefore, there is no legal aspect. However, if there is only one party wrong [such as the auditor], then the legal threat is to be jailed."

Referring to the above explanation, it can be concluded that the reliability and validity of the FV measurements are particularly vulnerable to bias when FV measurement is the result of management estimation. Therefore, it is reasonable to assume that the risks of a public accountant's lawsuit are high if he gives a wrong opinion. This is a consequence of the risk of the profession to be held by a public accountant, and this is also a form of legal responsibility of a public accountant as a citizen. Tuanakotta (2011: 193) states that public accounting firms understand the threat of litigation as an unavoidable risk in the practice of public accountants, but they reject the view that they provide absolute guarantees for the correctness of their audit opinion.

\subsection{Independence and Legal Responsibility of Auditors}

The independence is a typical way of dignity for the public accounting profession. Nonetheless, the public accounting profession is not immune from the law. The independence and legal responsibility are two-dimensional, among many other dimensions, which are closely related. Therefore, when the independence of the profession is violated, the guilty party must be responsible before the law. Thus, the collapse of Enron and Arthur Anderson is a valuable lesson from the case of weak independence of public accounting firms. Learning from Enron, one of many similar 
cases, the US government issued an SOA (Sarbanes Oxley-Act), which contains the rules and strict supervision of the public accounting profession (Moeller, 2004). The question is what is the relationship of SOA with the application of FVA?

FVA is the area of corporate responsibility, especially internal accountants, and internal auditors as part of corporate management. These are the parties that should be held accountable for their compliance with the standards. However, in Enron's case, it is no secret that between Enron and Arthur Andersen have great partnerships. Arthur Andersen not only as the external auditor of Enron but Enron also hire some of them as an internal auditor. In fact, they do a lot of things for example: sharing an office, sharing resources, and speaking in one language. Not only Enron did such a policy. The results of the IIA (Institute of Internal Accountant) research in 1996 in the US and Canada showed that $25 \%$ of companies surveyed found contracting with outside parties as internal auditors (Moeller, 2004). According to the results of the study, most of the work of internal auditors is done by the public accounting firm. This kind of relationship caused Enron and many other public accounting firms to engage in a serious scandal and enter as an internal auditor destroying the independence of the public accounting firm.

Therefore, if the SOA states that the public accounting firm is strictly prohibited from engaging in non-audit service provision. Furthermore, the assessment of the fairness of assets and liabilities is the responsibility of appraisals and actuaries. In Indonesia, the public accounting profession is regulated by Law no. 5 years 2011 . Admittedly, most of the rules contained in the law adopted from SOA (Tuanakotta, 2011). The purpose of the issuance of the law is to protect the public in general and the public accounting profession. Therefore, for the rules contained in the law to have law force, one important thing that cannot be avoided is the inclusion of sanctions for any actions that violate and be guilty by the court. The question is how does the Institute of Indonesian Institute of Accountants (IICPA) respond to the law? To answer this question, the following paragraphs are summarized from the results of IICPA discussions with several academicians to prepare for 'Review of Act No.' 5 Year 2011. 
Against the provisions of the Act, the IICPA does not oppose or reject the prohibition of providing services as regulated in regulation. The objection of IICPA also lies not in the consequences of imprisonment and/or penalty to be paid as regulated in Articles 55-57. As known, the articles stipulate that public accountants, associated parties, and any person who is found to be violating Law no. 5 year 2011, depending on the type of violation, shall be subject to a maximum imprisonment of 5 years and a maximum fine of Rp1, 000,000,000.00.

However, the burden of IICPA is allegations of violations of Law no. 5 years 2011. The threat of an alleged breach with 5 years in prison is considered very burdensome. The problem is that the parties mentioned are punishable by imprisonment as mentioned in articles 55 and 57, although in later cases not proven in court, public trust is destroyed, and it is not impossible that the public accounting firm is accused of being bankrupt is the same as Arthur Anderson's case. Therefore, since the publication of the draft law, IICPA actively protested. Furthermore, when Parliament has passed the legislation, this effort is then continued by IICPA to conduct judicial review.

Furthermore, in addition to penalty sanctions, another important note that should be underlined from Law no. 5 year 2011 article 55 is a public accountant is prohibited from providing services other than audit services and reviews of historical financial information (Article 3, paragraph 1). Although it does not set out in detail what is banned, it is clear that what is meant by Law No. 5 Year 2011 is consistent with SOA TITLE II. The prohibition relates to the independence of public accountants in FV measurement. In this case, public accountants are prohibited from providing "appraisal or valuation services, fairness opinions, or contribution-in-kind reports and actuarial services." That is if the FV measurement is applied thoroughly, the service becomes the authority and responsibility of the appraisal and independent actuary.

The implication of such regulation is the removal of the authority of public accountant in assessing the assets or liabilities that he or she enjoys in the auditing environment of the $\mathrm{HC}$ base. As a consequence of this situation rule, as previously described by MJW, the last party to be responsible for verifying the work made by 
management and appraisal is the auditor. Groeneveld $(2003,268)$ states that: "... an auditor is essentially a checking and certifying specialist. A valuator is a valuation specialist". If so, if the FV measurement is fully implemented, the essence of the work of a public accountant is nothing more than a "Checker." They are only required to match a long list of company obedience items for the adoption of FV measurements. Therefore, Ijiri (1961) criticized that the application of FV makes accountants the essence of the work of public accountants, from decision makers.

\section{Conclusions}

This study concludes that accountants from small and large public accounting firms perceive that auditing financial statements based on FV measurement is more difficult and has a higher risk when compared to the auditing of HC-based financial reporting. This condition arises because of the low validity and reliability of FV measurements, especially FV at level three. In other words, FV auditing is essentially auditing estimates.

In response to this condition, auditors from small accounting firms are not interested in or avoiding auditing FV-based financial statements and selecting clients that do not apply the FV basis. Conversely, auditors from large accounting firms continue to audit FV-based financial statements. However, as compensation for the difficulties and auditing risks of FV-based financial statements, the auditor requested additional audit fees. Another finding, from the aspect of independence and legal responsibility, which needs to be underlined from auditors' perceptions, is that the risk of an assignment is more daunting than audit risk. That is, auditors are more afraid of being punished as regulated by Law no. 5 of 2011 rather than a failed audit.

Limitation of this study is not all auditors encountered, for reasons of time and busy work, willing to be an informant. Therefore the data obtained and feasible to be analyzed is limited. Another reason to refuse interviews is not yet well understood understood FV measurement because the concept is considered new. The implications of this study for accountants are the need to improve their ability to understand the FV 
measurement with continuing education. Hopefully, the difficulties of the auditing of FV can be overcome, and the audit risk may be reduced.

\section{Reference}

AICPA. 2003. Auditing Fair Value Measurements and Disclosures. AU Section 328. New York, NY: AICPA.

AICPA. 2007. Statements On Standards For Valuation Services No. 1. Valuation of a Business, Business Ownership Interest, Security, or Intangible Asset. AU Section 100. New York, NY: AICPA

American Accounting Association (AAA). 2006. Statement of Financial Accounting Standards (SFAS) No. 157: Fair Value Measurements. Norwalk, CT: Financial Accounting Standards Board

Ball, R. 2005. International Financial Reporting Standards (IFRS): Pros and Cons for Investors. Paper. 1-63. Copy or electronic copy available at http://www.icaew.co.uk/cbp/index.cfm. Downloaded on 29 March 2010. At 12:25 PM.

Barlev, B., and Haddad, J.R. 2003. Fair Value Accounting and the Management of the Firm. Critical Perspectives on Accounting, 14, 383 - 415

Benston, G.J. 2008. The shortcomings of fair-value accounting described in SFAS 157. Journal of Accounting and Public Policy, 27, 101 - 114

Biondi, Y. and Suzuki. 2007. Socio-economic impacts of international accounting standards: an introduction. Socio-Economic Review, 5, 585-602.

Choy, A.K. 2006. Fair Value as a Relevant Metric: A Theoretical Investigation. Washington University. Paper. 1-56. Copy or electronic copy available at http://ssrn.com/abstract=878119. Downloaded on 13 April 2010. At, 11:41 AM.

Creswell, John W. 1998. Qualitative Inquiry and Research Design. Choosing Among Five Traditions. Sage Publications Inc.

Danbolt, J. and William, R. 2008._An Experiment in Fair Value Accounting: UK Investment Vehicles. European Accounting Review, 17_(2), 271-303.

Francis, J. ., and Katherine Schipper. 1999. Financial Statements. Have Lost Their Relevance? Journal of Accounting Research, 37 (2), 319 - 352

Fujioka, t., Seitaro, s., and Pongsak, H. 2008. The State of Fair Value Accounting, Global Financial Crisis and Implications to Thailand. Presentation for H.E. DPM Dr. Olarn at Sasin (17th Nov. 08). Paper. pp. 1-16. Copy or electronic copy available at http://ssrn.com/abstract=1303351. Downloaded 28 August 2010. At 1:09 PM. 
Groeneveld, J. G. 2003. Financial Statements Are A Result Of Policy And Not A Factor Informing Policy inside. Is Fair Value Fair? Financial Reporting in an International Perspective. Henk Lengendijk, Dirk M. Swagerman, and Willem Verhoog (Ed). England: Wiley \& Sons.

Gunn, J. L. 2008. The gray areas of bias. CA Magazine, 141 (4), 42-44

Hits, J. M. 2007. The Decision Usefulness of Fair Value Accounting: A Theoretical Perspective. European Accounting Review, 16_(2), 323-362.

IAASB. 2008. International Standard on Auditing (ISA) 540: Auditing Accounting Estimates, Including Fair Value Accounting Estimates, And Related Disclosures. Copy or electronic copy available at www.iasb.org. Downloaded date. May 26, 2010. O'clock: 30 PM.

IASB. 2008. The Conceptual Framework for Financial Reporting: The Objective of Financial Reporting and Qualitative Characteristics and Constraints of Decision-Useful Financial Reporting Information. Exposure Draft. Copy or electronic copy available at www.iasb.org. Downloaded date. August 19, 2010. At, 9:31 PM

IASB. 2009. Exposure Drafts: Fair Value Measurement. London: International Accounting Standards Board. Copy or electronic copy available at www.iasb.org. Downloaded date. April 23, 2010. O'clock. 11:05 AM.

Ijiri, Y. 1975. Theory of Accounting Measurement. Studies in Accounting Research No. 10. American Accounting Associations.

King, A.M. 2006. The Fair Value of The Financial Reporting. Meeting the New FASB Requirements. John Wiley \& Sons, Inc., Hoboken, New Jersey

King, A.M. 2008. Be careful what you ask for: Is fair value accounting really fair? International Journal of Disclosure and Governance. Vol. 5, 4, $301-311$

Lev, B. and Zarowin, P. 1999. The Boundaries of Financial Reporting and How to Extend Them. Journal of Accounting Research, 37, 353 - 385.

Mautz, R. K., and Sharaf, H. A. 1961. The Philosophy of Auditing. The American Accounting Association.

Moeller, Robert, R. 2004. Sarbanes-Oxley and the New Internal Auditing Rules. New Jersey: John Wiley \& Sons, Inc.

Penman. 2007. Financial Reporting Quality: is Fair Value a Plus or a Minus? Accounting \& Business Research,33-43.

Rayman, R.A. 2007. Fair value accounting and the present value fallacy: The need for an alternative conceptual framework. The British Accounting Review, 39, 211 - 225

Pannese, D., and Alan DelFavero. 2010. Fair Value Accounting: Affect On The Auditing Profession. Journal of Applied Business Research, 26 (3), 43-50. 
The Financial Accounting Standards Board (FASB). 2006. Statement of Financial Accounting Standards No. 157. Fair Value Measurements._Norwalk, CT: Financial Accounting Standards Board.

1980. Statement of Financial Accounting Concept No. 2: Qualitative Characteristics of Accounting Information. Norwalk, CT: Financial Accounting Standards Board

, 2006. Statement of Financial Accounting Standards No. 157:_Fair Value Measurements._Norwalk, CT: Financial Accounting Standards Board

Tuanakotta, T. M. 2011. Critical thinking in Auditing. Jakarta: four Salemba. 
The Indonesian Journal of Accounting Research - Jan, Vol. 21, No.1, 2018

intentionally blank 